\title{
PENGARUH PENAMBAHAN OLEORESIN DAUN JERUK PURUT (Citrus hystrix DC) PADA EDIBLE COATING TERHADAP PENGHAMBATAN KERUSAKAN OKSIDATIF DAN MIKROBIOLOGIS DAGING SAPI YANG DISIMPAN DI SUHU RENDAH
}

\author{
EFFECT OF KAFFIR LIME LEAVES (Citrus hystrix DC)OLEORESIN ADDITION ON \\ EDIBLE COATING TO OXIDATIVE AND MICROBIOLOGICAL DAMAGE INHIBITION \\ OF BEEF STORED IN LOW TEMPERATURE
}

\author{
Kawiji $^{(1)}$, Rohula Utami ${ }^{(1)}$, Lia Umi Khasanah ${ }^{(1)}$, Rahajeng Titi Nurdiani $^{(1)}$ \\ ${ }^{(1)}$ Prodi Ilmu dan Teknologi Pangan Universitas Sebelas Maret \\ J1. Ir. Sutami 36A Surakarta \\ Email : kawiji_kawiji@yahoo.co.id
}

\begin{abstract}
The purpose of this study was to determine the effect of various concentrations of kaffir lime leaves oleoresin applied at edible coating against microbiological decay (TPC), oxidative damage (TBA) and physicochemical damage (TVB, pH and color)of beef during storage at $4 \pm 1^{\circ} \mathrm{C}$. This research used Completely Randomized Design (CRD) with one factor, which was variety of kaffir lime leaves oleoresin concentration in edible coating solution that was $0 \%, 0.05 \%$, and $0.15 \%$. Observations were done on days $0,4,7,10$, and 14. The results showed that the addition of kaffir lime leaves oleoresin on edible coating of beef affect the oxidative and microbiological damage. The addition of kaffir lime leaves oleoresin decreased the amount of microbes and stabilize TVB and TBA values. $p H$ values did not change significantly during storage. The greater addition of oleoresin the more stable color of beef.
\end{abstract}

Keywords: beef, Citrus hystrix DC., edible coating, oleoresin

\section{ABSTRAK}

Tujuan penelitian ini adalah untuk mengetahui pengaruh penambahan berbagai konsentrasi oleoresin daun jeruk purut pada edible coatingterhadap karakteristik mikrobiologis (TPC) dan fisiko-kimia (TBA, TVB, $\mathrm{pH}$, dan warna) daging sapi selama penyimpanan pada suhu $4 \pm 1^{\circ} \mathrm{C}$. Rancangan percobaan yang digunakan adalah Rancangan Acak Lengkap (RAL) dengan satu faktor yaitu konsentrasi oleoresin daun jeruk purut pada edible coating ( $0 \%$; $0,05 \%$; dan $0,15 \%)$. Pengamatan dilakukan pada hari ke $0,4,7,10$, dan 14 . Hasil penelitian menunjukkan bahwa penambahan oleoresin daun jeruk purut pada edible coating daging sapi berpengaruh terhadap kerusakan oksidatif dan mikrobiologis daging sapi. Penambahan oleoresin daun jeruk purut menurunkan jumlah mikroba dan menstabilkan nilai TVB dan TBA. Nilai $\mathrm{pH}$ tidak berubah secara signifikan selama penyimpanan. Semakin besar penambahan oleoresin warna daging sapi semakin stabil.

Kata kunci: daging sapi, edible coating, daun jeruk purut, oleoresin

\section{PENDAHULUAN}

Daging sapi merupakan jaringan otot yang diperoleh dari sapi yang biasa dan umum digunakan untuk keperluan konsumsi makanan. Daging sapi memiliki nilai nutrisi yaitu protein, vitamin, mineral, lemak, asam lemak, dan kolesterol yang sangat bermanfaat bagi tubuh. Namun daging sapi juga memenuhi persyaratan untuk perkembangan mikroorganisme perusak dan pembusuk karena mempunyai kadar air yang tinggi (68-75\%), karena itulah daging sapi tergolong perishable (mudah rusak) sehingga menyebabkan daging sapi memiliki masa simpan yang rendah.
Kemasan antimikroba merupakan suatu kemasan yang dapat menghentikan, menghambat, mengurangi atau memperlambat pertumbuhan mikroorganisme pada makanan dan bahan kemasan. Kemasan ini dapat diaplikasikan ke daging sapi dengan salah satu caranya adalah menggunakan edible coating. Edible coating berperan sebagai pembatas fisik terhadap karbon dioksida, oksigen dan pergerakan kadar air. Penelitian terdahulu yang telah menggunakan edible coating antara lain dengan karaginan dan kitosan, namun belum ada yang menggunakan oleoresin daun jeruk purut sebagai bahan tambahan pada edible coating. Ekstrak daun jeruk purut 
mengandung senyawa-senyawa yang diketahui memiliki aktivitas antibakteri (Nanasombat and Lohasupthawee, 2005). Manfaat ini dapat digunakan untuk melengkapi fungsi edible coating dalam pengawetan bahan makanan, khususnya daging sapi.

Pemanfaatan daun jeruk purut pada umumnya sebagai bumbu masakan. Selain untuk bahan bumbu, daun dan kulit buah jeruk purut juga bisa didestilasi (disuling) untuk diambil minyak atsirinya (Foragri, 2012). Selain dalam bentuk minyak atsiri, ekstrak daun jeruk purut dapat juga dibuat dalam bentuk oleoresin yang lebih praktis dalam penggunaannya karena konsentrasinya lebih tinggi daripada minyak atsiri sehingga membutuhkan jumlah lebih sedikit untuk pengaplikasiannya. Sitronelal merupakan komponen utama yang terdapat dalam minyak daun jeruk purut. Oleoresin daun jeruk purut mengandung sitronelal 25,66\% sebagai komponen utama (Aryani, 2012).

Aplikasi oleoresin daun jeruk purut yang belum umum digunakan pada edible coating untuk daging sapi inilah yang melatarbelakangi penelitian ini dilakukan. Suhu rendah untuk penyimpanan daging sapi sangat dianjurkan dalam menghambat kerusakan mikrobiologis dan oksidatif, dan juga akan diterapkan dalam penelitian ini yaitu $4 \pm 1^{\circ} \mathrm{C}$. Faktor yang diteliti dalam penelitian ini adalah pengaruh penambahan oleoresin daun jeruk purut pada edible coating daging sapi terhadap penghambatan kerusakan mikrobiologis dan oksidatif selama penyimpanan dalam suhu rendah. Tujuan penelitian ini adalah untuk mengetahui pengaruh penambahan berbagai konsentrasi oleoresin daun jeruk purut pada edible coatingterhadap karakteristik mikrobiologis (TPC) dan fisiko-kimia (TBA, TVB, pH, dan warna) daging sapi selama penyimpanan pada suhu $4 \pm 1^{\circ} \mathrm{C}$.

\section{METODE PENELITIAN}

\section{Bahan dan Alat}

Oleoresin daun jeruk purut diperoleh dari ekstraksi maserasi daun jeruk purut dari Pasar Legi. Larutan edible coating dibuat dari tepung tapioka "Rose Brand", oleoresin daun jeruk purut, gliserol (Merck), dan aquadest. Daging sapi "yang diperoleh dari Pasar Legi, Surakarta. Plastik PP $0,8 \mathrm{~mm}$ sebagai pengemas sampel. Bahan yang digunakan untuk analisis TVB antara lain, larutan asam borat, indikator, larutan $7 \%$ trikloroasetat (TCA), larutan kalium karbonat $\left(\mathrm{K}_{2} \mathrm{CO}_{3}\right)$ jenuh, larutan $40 \%$ formalin, vaselin, larutan $10 \%$ formaldehid, pelarut toluene, larutan kalium hidroksida $(\mathrm{KOH})$, Kristal natrium sulfat $\left(\mathrm{Na}_{2} \mathrm{SO}_{4}\right)$ anhidrous, larutan $0,02 \%$ asam pikrat toluene, larutan stok trimethylamin asam klorida (TMA$\mathrm{HCl}$ ).Analisis TBA diperlukan bahan aquadest, larutan $\mathrm{HCl} 4 \mathrm{~N}$, asam asetat glasial 90\% (Merck), dan reagen TBA (Merck). Analisis TPC diperlukan Plate Count Agar (PCA) (Merck), aquadest dan $\mathrm{NaCl} \quad 0,85 \%$ (Oxoid). Analisis $\mathrm{pH}$ diperlukan aquadest, buffer $\mathrm{pH} 4$ dan 7 .

Alat yang digunakan dalam penelitian ini antara lain labu leher tiga, hot plate, pendingin balik, thermometer, rotary vacuum evaporator, corong, gelas ukur, pompa vakum dan kertas saring. Alat yang digunakan dalam pembuatan larutan edible coating adalah gelas beker $250 \mathrm{ml}$, hot plate, pipet volume, pengaduk, magnetic stirrer, termometer, timbangan analitik kepekaan $0,1 \mathrm{mg}$, blender yang dilengkapi pengatur kecepatan putaran, blender jari dari stainless steel kapasitas $100 \mathrm{ml}$, stop watch, erlenmeyer $250 \mathrm{ml}$, corong, kertas saring diameter $15 \mathrm{~cm}$, gelas ukur $100 \mathrm{ml}$, cawan conway diameter $6 \mathrm{~cm}$ beserta tutupnya, inkubator, buret $2 \mathrm{ml}$ yang berskala $0,05 \quad \mathrm{ml}$, spektrofotometerUV Mini-1240, 220-240, mortar, labu destilasi, pengaduk, penangas air, spektrofotometerUV Mini-1240, 220240 , tabung reaksi, pipet mikro, petridish, vortex, botol media, colony counter, jarum oose, pembakar Bunsen, autoklaf, laminar air flow, refrigerator, $\mathrm{pH}$ meter EUTECH, Chromameter Konica Minolta CR 400/410.

\section{Tahapan Penelitian}

Pembuatan Oleoresin Daun Jeruk Purut 
Oleoresin daun jeruk purut pada penelitian ini didapatkan dari hasil ekstraksi maserasi dan evaporasi. Daun jeruk purut bersih dilakukan perajangan dengan ukuran sekitar 1-1,5 cm. Setelah perajangan, daun jeruk purut dimasukkan ke labu leher tiga dan direndam dengan etanol 96\% dengan perbandingan 1:5 (daun jeruk purut:etanol) dan dilakukan maserasi dengan suhu $78^{\circ} \mathrm{C}$ selama 5 jam 27 menit. Setelah didapatkan ekstrak daun jeruk purut, dilakukan evaporasi dengan rotary evaporator pada suhu $80^{\circ} \mathrm{C}$ dengan kecepatan $100 \mathrm{rpm}$ (Aryani, 2012). Proses ini dihentikan saat pelarut etanol sudah teruapkan seluruhnya yaitu saat tidak ada lagi pelarut yang menetes ke dalam labu yang berisi pelarut dan didapatkan oleoresin daun jeruk purut.

\section{Pembuatan Edible Coating}

Edible coating dibuat dengan menggunakan aquadest, gliserol, pati tapioka, dan oleoresin dengan berbagai konsentrasi. Menurut Olivas dan BarbosaCanovas (2005) gliserol berperan sebagai plasticizer untuk memperbaiki sifat edible coating seperti kekakuan dan fleksibilitas.

\section{Aplikasi Edible Coating pada Daging Sapi}

Edible coating yang dihasilkan dari kombinasi larutan pati tapioka, gliserol, dan oleoresin dengan berbagai konsentrasi $(0 \% ; 0,05 \%$; dan 0,15\%) diaplikasikan dengan cara pencelupan daging sapi ke dalam larutan coating. Pencelupan dilakukan dua kali agar merata kemudian digantung dan dikeringkan dengan menggunakan pengering (dryer). Daging sapi yang telah mengalami coating dimasukkan ke styrofoam dan ditutup dengan plastic wrap dan disimpan pada suhu rendah yaitu $4 \pm 1^{\circ} \mathrm{C}$ selama waktu yang ditentukan untuk pengujian pada hari ke $0,4,7,10$, dan 14 .

\section{Pengujian Kerusakan Oksidatif dan Mikrobiologis Daging Sapi}

Daging sapi yang telah mengalami coating kemudian disimpan dalam pendingin dengan suhu $4 \pm 1^{\circ} \mathrm{C}$. Analisis yang dilakukan meliputi uji kimia (TVB,
TBA, pH, dan warna) dan uji mikrobiologi (TPC). Masing-masing analisis dilakukan pada hari ke 0, 4, 7, 10, dan 14. Untuk pengujian hari ke 0 dilakukan \pm 8 jam setelah daging sapi diberi perlakuan coating.

\section{Rancangan Percobaan}

Rancangan percobaan yang digunakan dalam penelitian ini adalah Rancangan Acak Lengkap (RAL) dengan satu faktor, yaitu variasi konsentrasi oleoresin daun jeruk purut dengan ulangan sampel sebanyak 2 kali dan ulangan analisis sebanyak 2 kali. Data yang diperoleh dianalisis dengan menggunakan ANOVA $(\alpha=0,05)$. Jika terdapat perbedaan maka akan dilanjutkan dengan uji Duncan Multiple Range Test (DMRT) untuk mengetahui ada tidaknya perbedaan pada masing-masing sampel pada tingkat signifikansi $\alpha=0,05$.

\section{HASIL DAN PEMBAHASAN}

\section{Total Plate Count (TPC)}

Dari hasil Total Plate Count (TPC) yang ditunjukkan pada Tabel 1 dapat diketahui bahwa jumlah mikroba semakin meningkat di setiap hari pengamatan untuk semua perlakuan. Aktivitas mikrobial dalam daging dipengaruhi oleh faktor ekstrinsik dan faktor instrinsik. Faktor ekstrinsik meliputi temperatur, kelembaban relatif, oksigen dan kondisi fisik daging. Sedangkan faktor instrinsik meliputi nutrisi, air, $\mathrm{pH}$, potensi oksidasi-reduksi, kebutuhan nutrien, substansi penghambat, jaringan pelindung. Temperatur sangat menentukan laju pertumbuhan dan jumlah mikroorganisme pada daging. Temperatur $5^{\circ} \mathrm{C}$ dianggap sebagai temperatur kritis selama penanganan dan penyimpanan daging, sebab pada temperatur di bawah $5^{\circ} \mathrm{C}$ cenderung menghambat dan menekan pertumbuhan mikroorganisme perusak, pembusuk, dan hampir semua mikroorganisme pathogen (Nurwantoro dan Mulyani, 2003). Selain itu, dalam ekstrak daun jeruk purut mengandung senyawa $\beta$-pinen, sabinen, sitronelal, linalool yang berkontribusi dalam aktivitas 
Tabel 1 Total Plate Count (TPC) Daging Sapi dengan Edible Coating Oleoresin Daun Jeruk Purut Selama Penyimpanan pada Suhu $4 \pm 1^{\circ} \mathrm{C}(\log \mathrm{CFU} / \mathrm{g}$ sampel)

\begin{tabular}{llllll}
\hline \multirow{2}{*}{ Sampel } & \multicolumn{5}{c}{ Lama Penyimpanan (Hari) } \\
\cline { 2 - 6 } & 0 & 4 & 7 & 10 & 14 \\
\hline Konsentrasi 0\% & $3,33 \pm 0,10^{\mathrm{A}}{ }_{\mathrm{a}}$ & $3,52 \pm 0,06^{\mathrm{A}}{ }_{\mathrm{a}}$ & $4,21 \pm 0,44^{\mathrm{B}}{ }_{\mathrm{a}}$ & $3,78 \pm 0,81^{\mathrm{AB}}{ }_{\mathrm{a}}$ & $6,23 \pm 0,73^{\mathrm{C}}{ }_{\mathrm{a}}$ \\
Konsentrasi 0,05\% & $3,30 \pm 0,06^{\mathrm{A}}{ }_{\mathrm{a}}$ & $3,25 \pm 0,37^{\mathrm{A}}{ }_{\mathrm{a}}$ & $4,13 \pm 0,02^{\mathrm{B}}{ }_{\mathrm{a}}$ & $4,12 \pm 0,29^{\mathrm{AB}}{ }_{\mathrm{a}}$ & $5,73 \pm 0,55^{\mathrm{C}}{ }_{\mathrm{a}}$ \\
Konsentrasi $0,15 \%$ & $3,20 \pm 0,12^{\mathrm{A}}{ }_{\mathrm{a}}$ & $3,26 \pm 0,31^{\mathrm{A}}{ }_{\mathrm{a}}$ & $4,42 \pm 0,17^{\mathrm{B}}{ }_{\mathrm{a}}$ & $4,23 \pm 0,26^{\mathrm{B}}{ }_{\mathrm{a}}$ & $5,27 \pm 0,27^{\mathrm{C}}{ }_{\mathrm{a}}$ \\
\hline
\end{tabular}

Keterangan: Subscript yang sama pada kolom yang sama dan superscript yang sama pada baris yang sama menunjukkan tidak beda nyata pada taraf signifikansi $(\alpha=0,05)$

Tabel 2 Total Volatile Bases (TVB) Daging Sapi dengan Edible Coating Oleoresin Daun Jeruk Purut Selama Penyimpanan pada Suhu $4 \pm 1^{\circ} \mathrm{C}(\mathrm{mg} \mathrm{N} / 100 \mathrm{~g})$

\begin{tabular}{lcccll}
\hline \multirow{2}{*}{ Sampel } & \multicolumn{5}{c}{ Lama Penyimpanan (Hari) } \\
\cline { 2 - 6 } & 0 & 4 & 7 & 10 & 14 \\
\hline Konsentrasi 0\% & $19,08 \pm 1,70^{\mathrm{A}}{ }_{\mathrm{a}}$ & $30,42 \pm 0,51^{\mathrm{B}}{ }_{\mathrm{b}}$ & $33,23 \pm 0,86^{\mathrm{BC}}{ }_{\mathrm{b}}$ & $32,63 \pm 3,32^{\mathrm{BC}}{ }_{\mathrm{b}}$ & $35,14 \pm 0,14^{\mathrm{C}}{ }_{\mathrm{b}}$ \\
Konsentrasi 0,05\% & $16,84 \pm 0,58^{\mathrm{A}}{ }_{\mathrm{a}}$ & $20,26 \pm 1,91^{\mathrm{A}}{ }_{\mathrm{a}}$ & $18,87 \pm 0,86^{\mathrm{A}}{ }_{\mathrm{a}}$ & $21,01 \pm 1,75^{\mathrm{A}}{ }_{\mathrm{a}}$ & $18,74 \pm 3,79^{\mathrm{A}}{ }_{\mathrm{a}}$ \\
Konsentrasi $0,15 \%$ & $15,62 \pm 1,45^{\mathrm{A}}{ }_{\mathrm{a}}$ & $20,41 \pm 0,43^{\mathrm{A}}{ }_{\mathrm{a}}$ & $17,55 \pm 0,80^{\mathrm{A}}{ }_{\mathrm{a}}$ & $17,85 \pm 4,91^{\mathrm{A}}{ }_{\mathrm{a}}$ & $17,32 \pm 1,88^{\mathrm{A}}{ }_{\mathrm{a}}$ \\
\hline
\end{tabular}

Keterangan: Subscript yang sama pada kolom yang sama dan superscript yang sama pada baris yang sama menunjukkan tidak beda nyata pada taraf signifikansi $(\alpha=0,05)$

antimikroba (Chanthaphon et. al., 2008; Cushnie and Lamb, 2005) sehingga membantu menghambat pertumbuhan mikroba.

Pada perlakuan tanpa penambahan oleoresin daun jeruk purut (konsentrasi $0 \%$ jumlah mikroba meningkat dari 3,33 $\log \mathrm{CFU} / \mathrm{g}$ pada hari ke 0 menjadi 6,23 log $\mathrm{CFU} / \mathrm{g}$ pada hari ke 14. Sedangkan pada perlakuan penambahan oleoresin daun jeruk purut konsentrasi $0,05 \%$ jumlah mikroba meningkat dari 3,30 log CFU/g pada hari ke 0 menjadi 5,73 log CFU/g pada hari ke 14. Pada perlakuan penambahan oleoresin daun jeruk purut konsentrasi $\quad 0,15 \%$ jumlah mikroba meningkat dari 3,20 log CFU/g pada hari ke 0 menjadi 5,27 $\log$ CFU/g pada hari ke 14. Pada sampel tanpa penambahan oleoresin daun jeruk purut (konsentrasi $0 \%$ menunjukkan kenaikan jumlah mikroba yang paling banyak dibandingkan dengan sampel yang ditambahkan oleoresin daun jeruk purut konsentrasi $0,05 \%$ dan $0,15 \%$ sampai pada akhir waktu pengamatan. Sedangkan sampel dengan penambahan oleoresin daun jeruk purut konsentrasi $0,15 \%$ memberikan hasil jumlah mikroba yang paling rendah dibandingkan dengan perlakuan penambahan oleoresin daun jeruk purut
$0,05 \%$ dan tanpa penambahan oleoresin daun jeruk purut (konsentrasi $0 \%$ ). Pada hari ke 7 daging sapi dengan semua perlakuan memiliki jumlah mikroba yang lebih tinggi daripada hari ke 10, hal ini dapat disebabkan karena mikroba sedang berada pada fase pertumbuhan yaitu saat pembiakan mikroba berlangsung cepat. Tren yang sama juga terjadi pada hasil penelitian yang dilakukan oleh Kingchaiyamphum and Rachtanapun (2012) yang memperlihatkan bahwa mikroba tumbuh pada sampel sosis Cina semakin lama semakin banyak seiring dengan lamanya penyimpanan, namun kenaikan jumlah mikroba semakin kecil seiring dengan semakin tingginya konsentrasi minyak atsiri kulit daun jeruk purut yang diaplikasikan pada sampel.

\section{Total Volatil Bases (TVB)}

Dari data analisis yang ditunjukkan pada Tabel 2 diketahui bahwa nilai TVB daging sapi pada perlakuan konsentrasi $0 \%$ pada hari ke 0 sebesar 19,08 mg N/100 g mengalami kenaikan menjadi $34,14 \mathrm{mg}$ $\mathrm{N} / 100$ g pada akhir penyimpanan yaitu hari ke 14. Pada perlakuan konsentrasi $0,05 \%$ pada hari ke 0 sebesar 16,84 $\mathrm{mg} \mathrm{N} / 100 \mathrm{~g}$ mengalami kenaikan menjadi $18,74 \mathrm{mg}$ N/100 g di hari ke 14 dan perlakuan 
konsentrasi $0,15 \%$ pada hari ke 0 sebesar $15,62 \mathrm{mg} \mathrm{N} / 100 \mathrm{~g}$ mengalami kenaikan menjadi 17,32 mg N/100 g pada hari ke 14 . Dari ketiga konsentrasi penambahan oleoresin daun jeruk purut tersebut, kenaikan paling tinggi dialami oleh sampel daging sapi dengan perlakuan konsentrasi 0\%. Dalam Kasmadiharja (2008) batas maksimal untuk TVB yang terkandung dalam bahan adalah $30 \mathrm{mg} \mathrm{N} / 100 \mathrm{~g}$. Nilai TVB meningkat dapat dikarenakan degradasi protein sehingga semakin tinggi TVB, semakin banyak protein yang telah rusak. Komponen yang ada dalam TVB menurut Kasmadiharja (2008) adalah amonia, $\mathrm{H}_{2} \mathrm{~S}$ dan senyawa volatil lainnya.

Pada penelitian yang dilakukan oleh Ali et. al., (2010) juga ditemukan bahwa sampel yang diberi propolis terus mengalami peningkatan nilai TVB sampai akhir pengamatan dan belum melewati batas aman pada akhir pengamatan. Namun dalam penelitian ini nilai TVB cenderung lebih stabil daripada penelitian yang dilakukan oleh Ali et. al., (2010) sehingga penggunaan oleoresin daun jeruk purut pada penelitian ini terbukti dapat mempertahankan daging sapi lebih efektif ditinjau dari nilai TVB yang lebih stabil.

\section{Thiobarbituric Acid (TBA)}

Dari Tabel 3 dapat dilihat bahwa nilai TBA pada sampel dengan penambahan oleoresin daun jeruk purut konsentrasi $0 \%$ berbeda nyata sejak hari ke 4 sampai hari ke 14 dengan konsentrasi $0,05 \%$ dan $0,15 \%$ pada taraf signifikansi $\alpha=0,05$. Pada awal hingga akhir penyimpanan, nilai TBA tertinggi yaitu pada konsentrasi $0 \%$ dan yang paling rendah adalah konsentrasi $0,15 \%$. Pada perlakuan $0 \%$ nilai TBA pada hari ke 0 meningkat dari $0,29 \mathrm{mg}$ malonaldehid $/ \mathrm{kg}$ menjadi $0,48 \mathrm{mg}$ malonaldehid/kg pada hari ke 14. Sedangkan pada perlakuan $0,05 \%$ nilai TBA pada hari ke 0 meningkat dari $0,14 \mathrm{mg}$ malonaldehid $/ \mathrm{kg}$ menjadi $0,28 \mathrm{mg}$ malonaldehid $/ \mathrm{kg}$ pada hari ke 14 dan pada perlakuan $0,15 \%$ nilai TBA pada hari ke 0 meningkat dari $0,14 \quad \mathrm{mg}$ malonaldehid/kg menjadi 0,13 $\mathrm{mg}$ malonaldehid/kg pada hari ke 14. Pada sampel dengan penambahan oleoresin daun jeruk purut konsentrasi $0 \%$ menunjukkan nilai TBA paling tinggi dibandingkan dengan konsentrasi penambahan oleoresin daun jeruk purut $0,05 \%$ dan $0,15 \%$ pada setiap harinya. Tren yang serupa juga ditemukan pada penelitian yang dilakukan oleh Kingchaiyamphum and Rachtanapun (2012) menunjukkan bahwa sampel sosis Cina yang tidak diberi minyak atsiri kulit daun jeruk purut mengalami peningkatan signifikan pada hari ke 5 dan terus meningkat sampai akhir pengamatan, sedangkan sampel yang diberi minyak atsiri daun jeruk purut cenderung stabil dari awal hingga akhir hari pengamatan.

Pada penelitian ini memperlihatkan bahwa sampel dengan konsentrasi 0\% sudah melewati batas maksimal nilai TBA yaitu $0,5 \mathrm{mg}$ malonaldehid/ $\mathrm{kg}$ yang menurut Shon et. al. (2010) nilai tersebut sebagai nilai ambang batas persepsi ketengikan oleh konsumen sejak hari ke 4 . Sedangkan untuk sampel yang diberi penambahan oleoresin daun jeruk purut berada di bawah batas maksimal nilai TBA sampai akhir hari pengamatan. Hal ini dikarenakan oleoresin daun jeruk purut mengandung flavonoid yang merupakan bahan antioksidan yang mampu menetralisir oksigen reaktif (Devi dkk, 2010). Flavonoid yang terkandung dalam oleoresin daun jeruk purut adalah linalool yang menurut penelitian yang dilakukan oleh Keawsa-ard and Kongtaweelert (2012) memperlihatkan aktivitas antioksidan. Kandungan linalool dalam oleoresin daun jeruk purut sebesar 5,56\% (Aryani, 2012).

\section{Uji pH}

Dari hasil analisis tingkat keasaman (pH) yang ditunjukkan pada Tabel 4 dapat diketahui bahwa nilai $\mathrm{pH}$ selama masa penyimpanan sampel tanpa penambahan oleoresin daun jeruk purut (konsentrasi $0 \%$ ) mengalami peningkatan sampai hari ke 7 kemudian turun pada hari ke 10 dan mengalami peningkatan pada hari ke 14, namun tidak beda nyata. Sedangkan sampel dengan penambahan oleoresin daun jeruk purut konsentrasi $0,05 \%$ dan $0,15 \%$ 
Tabel 3 Thiobarbituric Acid (TBA) Daging Sapi dengan Edible Coating Oleoresin Daun Jeruk Purut Selama Penyimpanan pada Suhu $4 \pm 1^{\circ} \mathrm{C}$ (mg malonaldehid/kg)

\begin{tabular}{ccccll}
\hline \multirow{2}{*}{ Sampel } & \multicolumn{5}{c}{ Lama Penyimpanan (Hari) } \\
\cline { 2 - 6 } & 0 & 4 & 7 & 10 & 14 \\
\hline Konsentrasi 0\% & $0,29 \pm 0,28^{\mathrm{A}}{ }_{\mathrm{a}}$ & $0,53 \pm 0,12^{\mathrm{A}}{ }_{\mathrm{b}}$ & $0,57 \pm 0,00^{\mathrm{A}}{ }_{\mathrm{c}}$ & $0,59 \pm 0,00^{\mathrm{A}}{ }_{\mathrm{b}}$ & $0,48 \pm 0,01^{\mathrm{A}}{ }_{\mathrm{c}}$ \\
Konsentrasi $0,05 \%$ & $0,14 \pm 0,00^{\mathrm{A}}{ }_{\mathrm{a}}$ & $0,25 \pm 0,01^{\mathrm{D}}{ }_{\mathrm{a}}$ & $0,20 \pm 0,00^{\mathrm{B}}{ }_{\mathrm{b}}$ & $0,23 \pm 0,00^{\mathrm{C}}{ }_{\mathrm{a}}$ & $0,28 \pm 0,00^{\mathrm{E}_{b}}$ \\
Konsentrasi $0,15 \%$ & $0,14 \pm 0,00^{\mathrm{A}}{ }_{\mathrm{a}}$ & $0,18 \pm 0,00^{\mathrm{C}}{ }_{\mathrm{a}}$ & $0,16 \pm 0,00^{\mathrm{B}}{ }_{\mathrm{a}}$ & $0,22 \pm 0,01^{\mathrm{D}}{ }_{\mathrm{a}}$ & $0,13 \pm 0,01^{\mathrm{A}}{ }_{\mathrm{a}}$ \\
\hline
\end{tabular}

Keterangan: Subscript yang sama pada kolom yang sama dan superscript yang sama pada baris yang sama menunjukkan tidak beda nyata pada taraf signifikansi $(\alpha=0,05)$

Tabel 4 Nilai pH Daging Sapi dengan Edible Coating Oleoresin Daun Jeruk Purut Selama Penyimpanan pada Suhu $4 \pm 1^{\circ} \mathrm{C}$

\begin{tabular}{lcllll}
\hline \multirow{2}{*}{ Sampel } & \multicolumn{5}{c}{ Lama Penyimpanan (Hari) } \\
\cline { 2 - 6 } & 0 & 4 & 7 & 10 & 14 \\
\hline Konsentrasi 0\% & $5,36 \pm 0,02^{\mathrm{A}}{ }_{\mathrm{a}}$ & $5,42 \pm 0,02^{\mathrm{A}}{ }_{\mathrm{a}}$ & $5,49 \pm 0,13^{\mathrm{A}}{ }_{\mathrm{a}}$ & $5,36 \pm 0,04^{\mathrm{A}}{ }_{\mathrm{b}}$ & $5,50 \pm 0,12^{\mathrm{A}}{ }_{\mathrm{a}}$ \\
Konsentrasi 0,05\% & $5,37 \pm 0,03^{\mathrm{A}}{ }_{\mathrm{a}}$ & $5,48 \pm 0,12^{\mathrm{A}}{ }_{\mathrm{a}}$ & $5,41 \pm 0,10^{\mathrm{A}}{ }_{\mathrm{a}}$ & $5,20 \pm 0,02^{\mathrm{A}}{ }_{\mathrm{a}}$ & $5,30 \pm 0,00^{\mathrm{A}}{ }_{\mathrm{a}}$ \\
Konsentrasi $0,15 \%$ & $5,48 \pm 0,07^{\mathrm{A}}{ }_{\mathrm{a}}$ & $5,52 \pm 0,03^{\mathrm{A}}{ }_{\mathrm{a}}$ & $5,46 \pm 0,23^{\mathrm{A}}{ }_{\mathrm{a}}$ & $5,28 \pm 0,01^{\mathrm{A}}{ }_{\mathrm{ab}}$ & $5,39 \pm 0,01^{\mathrm{A}}{ }_{\mathrm{a}}$ \\
\hline
\end{tabular}

Keterangan: Subscript yang sama pada kolom yang sama dan superscript yang sama pada baris yang sama menunjukkan tidak beda nyata pada taraf signifikansi $(\alpha=0,05)$

mengalami peningkatan dari hari ke 0 menuju hari ke 4, kemudian terus turun sampai hari ke 10 dan naik lagi pada hari ke 14. Namun pada ketiga perlakuan konsentrasi ini tidak berbeda nyata selama hari pengamatan. Perubahan $\mathrm{pH}$ selama penyimpanan beku juga disebabkan oleh perubahan konsentrasi fraksi yang tidak beku akibat keluarnya air membentuk kristal es (Kasmadiharja, 2008). Menurut Komariah dkk (2004) setelah hewan mati metabolisme aerobik tidak terjadi karena sirkulasi darah yang membawa oksigen ke jaringan otot terhenti, sehingga metabolisme berubah menjadi sistem anaerobik yang menyebabkan terbentuknya asam laktat. Penimbunan asam laktat dalam daging menyebabkan turunnya $\mathrm{pH}$ jaringan otot.

\section{Warna}

Dari hasil analisis warna yang ditunjukkan pada Tabel 5 dapat diketahui bahwa dari parameter kecerahan $\mathrm{L}^{*}$ untuk konsentrasi $0 \%$ cenderung mengalami kenaikan, yang berarti sampel semakin cerah yaitu dari hari ke 0 sebesar 37,49 menjadi 43,00 di hari ke 14. Untuk konsentrasi $0,05 \%$ tingkat kecerahan menurun, dari 39,97 pada hari ke 0 menjadi 38,10 pada hari ke 14 . Begitu juga konsentrasi $0,15 \%$, tingkat kecerahan menurun dari 39,13 pada hari ke 0 menjadi 38,72 pada hari ke 14. Ditinjau dari parameter warna kemerahan sampel dengan perlakuan konsentrasi $0 \%, 0,05 \%$, dan $0,15 \%$ mengalami penurunan berturutturut dari 12,01 menjadi 9,69, dari 13,40 menjadi 11,09 , dan dari 12,09 menjadi 11,63 . Untuk parameter warna kekuningan konsentrasi $0 \%$ mengalami kenaikan dari 8,21 pada hari ke 0 menjadi 9,9 pada hari ke 14 , sedangkan pada konsentrasi $0,05 \%$ mengalami penurunan dari 10,83 pada hari ke 0 menjadi 7,11 pada hari ke 14. Sampel dengan perlakuan $0,15 \%$ mengalami penurunan dari 8,87 pada hari ke 0 menjadi 8,72 pada hari ke 14 .

Pada parameter kecerahan (L*) sampel tanpa penambahan oleoresin (konsentrasi 0\%) cepat mengalami peningkatan seiring dengan lama penyimpanan dibandingkan sampel dengan perlakuan konsentrasi $0,05 \%$ dan $0,15 \%$. Sampel dengan perlakuan konsentrasi $0,15 \%$ cenderung lebih stabil antara awal penyimpanan hingga akhir penyimpanan daripada perlakuan lainnya. Mioglobin dan oksimioglobin memiliki kapasitas untuk kehilangan satu elektron (disebut oksidasi) yang mengubah pigmen menjadi warna coklat dan menghasilkan metmioglobin. 
Tabel 5 Intensitas Warna (Chroma) Daging Sapi dengan Edible Coating Oleoresin Daun Jeruk Purut Selama Penyimpanan pada Suhu $4 \pm 1^{\circ} \mathrm{C}$

\begin{tabular}{|c|c|c|c|c|c|c|}
\hline \multirow{2}{*}{\multicolumn{2}{|c|}{ Perlakuan }} & \multicolumn{5}{|c|}{ Hari Penyimpanan (Hari) } \\
\hline & & 0 & 4 & 7 & 10 & 14 \\
\hline \multirow{3}{*}{$\mathrm{L}^{*}$} & $0 \%$ & $37,49 \pm 0,26_{a}^{\mathrm{A}}$ & $40,12 \pm 0,71_{a}^{\mathrm{B}}$ & $41,54 \pm 1,21^{\mathrm{BC}}$ & $42,31 \pm 0,36_{a}^{C}$ & $43,00 \pm 0,04^{\mathrm{C}}$ \\
\hline & $0,05 \%$ & $39,97 \pm 0,41_{\mathrm{a}}^{\mathrm{CD}}$ & $40,63 \pm 1,30^{\mathrm{D}}$ & $35,56 \pm 1,51_{a}^{\mathrm{A}}$ & $36,80 \pm 0,40^{\mathrm{AB}}$ & $38,10 \pm 0,13^{\mathrm{BC}}$ \\
\hline & $0,15 \%$ & $39,13 \pm 1,87_{a}^{\mathrm{A}}$ & $37,74 \pm 0,25^{\mathrm{A}}{ }_{\mathrm{a}}$ & $36,40 \pm 0,95^{\mathrm{A}}$ & $37,63 \pm 2,63^{\mathrm{A}}{ }_{\mathrm{a}}$ & $38,72 \pm 0,76_{a}^{\mathrm{A}}$ \\
\hline \multirow{3}{*}{$a^{*}$} & $0 \%$ & $12,01 \pm 0,69^{\mathrm{A}}{ }_{\mathrm{a}}$ & $11,66 \pm 1,14^{\mathrm{A}}{ }_{\mathrm{a}}$ & $12,63 \pm 2,82^{\mathrm{A}}$ & $10,84 \pm 0,31_{b}^{A}$ & $9,69 \pm 1,26_{a}^{\mathrm{A}}$ \\
\hline & $0,05 \%$ & $13,40 \pm 0,11^{\mathrm{C}}$ & $13,01 \pm 1,34^{\mathrm{C}}{ }_{\mathrm{a}}$ & $8,49 \pm 0,20_{a}^{\mathrm{A}}$ & $7,71 \pm 0,04_{\mathrm{a}}^{\mathrm{A}}$ & $11,09 \pm 0,04^{\mathrm{B}}$ \\
\hline & $0,15 \%$ & $12,09 \pm 1,41_{\mathrm{a}}^{\mathrm{A}}$ & $12,09 \pm 1,67^{\mathrm{A}}$ & $12,59 \pm 0,26^{\mathrm{A}}$ & $10,76 \pm 0,37^{\mathrm{A}}$ & $11,63 \pm 0,82_{a}^{\mathrm{A}}$ \\
\hline \multirow{3}{*}{$b^{*}$} & $0 \%$ & $8,21 \pm 0,59_{a}^{\mathrm{A}}$ & $8,42 \pm 0,06_{a}^{\mathrm{A}}$ & $9,67 \pm 0,32^{\mathrm{B}}{ }_{\mathrm{b}}$ & $10,61 \pm 0,68^{\mathrm{B}}{ }_{\mathrm{b}}$ & $9,90 \pm 0,45^{\mathrm{B}}$ \\
\hline & $0,05 \%$ & $10,83 \pm 0,78^{\mathrm{C}}{ }_{\mathrm{a}}$ & $10,29 \pm 0,05^{\mathrm{C}}$ & $5,16 \pm 0,38_{a}^{\mathrm{A}}$ & $5,84 \pm 0,19^{\mathrm{A}}{ }_{\mathrm{a}}$ & $7,11 \pm 0,25^{\mathrm{B}}$ \\
\hline & $0,15 \%$ & $8,87 \pm 1,17_{\mathrm{a}}^{\mathrm{A}}$ & $8,89 \pm 0,06^{\mathrm{A}}{ }_{\mathrm{b}}$ & $8,83 \pm 0,16^{\mathrm{A}}{ }_{\mathrm{b}}$ & $6,70 \pm 0,28_{a}^{\mathrm{A}}$ & $8,72 \pm 0,63^{\mathrm{A}}{ }_{\mathrm{b}}$ \\
\hline
\end{tabular}

Keterangan: Subscript yang sama pada kolom yang sama dan superscript yang sama pada baris yang sama menunjukkan tidak beda nyata pada taraf signifikansi $(\alpha=0,05)$

Demikian, mioglobin dapat berubah dari ungu gelap menjadi merah cerah secara sederhana dari oksigenasi atau menjadi warna coklat dengan kehilangan elektron. Pigmen mioglobin, oksimioglobin, dan metmioglobin dapat diubah menjadi satu sama lain, tergantung dengan kondisi penyimpanan daging. Setelah pemasakan, pigmen coklat yang disebut metmioglobin yang terdenaturasi terbentuk, yang secara normal tidak dapat diubah membentuk pigmen yang lain (Boles and Pegg, 1998). Perubahan mioglobin dari ungu gelap menjadi merah cerah diduga sebagai penyebab peningkatan kecerahan dari sampel dengan konsentrasi $0 \%$, sedangkan pada sampel dengan konsentrasi $0,05 \%$ dan $0,15 \%$ proses ini dihambat oleh antioksidan yang terkandung dalam oleoresin daun jeruk purut sehingga tingkat kecerahan cenderung stabil.

Pada parameter warna kemerahan $\left(\mathrm{a}^{*}\right)$, sampel tanpa penambahan oleoresin (konsentrasi $0 \%$ ) cenderung mengalami penurunan. Begitu pula intensitas warna kemerahan $\left(\mathrm{a}^{*}\right)$ pada sampel dengan perlakuan konsentrasi $0,05 \%$ yang mengalami penurunan cukup drastis dibandingkan sampel dengan perlakuan lain. Sampel dengan konsentrasi 0,15\% merupakan sampel dengan fluktuasi warna kemerahan paling stabil dibandingkan sampel dengan perlakuan konsentrasi $0 \%$ dan $0,15 \%$. Nilai $\mathrm{pH}$ akhir yang dicapai mempunyai pengaruh yang berarti terhadap kualitas daging yaitu pada $\mathrm{pH}$ rendah $( \pm 5,1)$ menyebabkan warna merah cerah yang disukai oleh konsumen, mempunyai struktur terbuka yang sangat diinginkan untuk pengasinan daging, flavor lebih disukai dalam kondisi telah dimasak atau diasin dan mempunyai stabilitas yang lebih baik terhadap kerusakan oleh mikroorganisme. Penurunan tingkat kemerahan dapat terjadi karena pada $\mathrm{pH}$ tinggi (6,2 sampai 7,2) menyebabkan daging pada tahap akhir mempunyai struktur yang tertutup atau padat dengan warna merah ungu tua, rasa kurang enak dan keadaan yang memungkinkan untuk perkembangan mikroorganisme (Buckle et. al., 1987). Penelitian yang dilakukan Camo et. al. (2011) menunjukkan bahwa kehadiran antioksidan menghasilkan penghambatan pembentukan metmioglobin yang signifikan, sehingga mioglobin yang dapat berubah menjadi metmioglobin melalui proses oksidasi dapat terhambat dengan adanya antioksidan yang terdapat pada produk, yang dalam penelitian ini didapatkan dari penambahan oleoresin daun jeruk purut. Sesuai dengan hasil penelitian yang memperlihatkan pada sampel dengan konsentrasi oleoresin $0,15 \%$ cenderung memiliki warna merah lebih stabil daripada sampel dengan konsentrasi oleoresin $0 \%$ dan $0,05 \%$. 
Pada parameter warna kekuningan (b*) sampel tanpa penambahan oleoresin (konsentrasi $0 \%$ ) cenderung mengalami kenaikan, yang mengindikasikan warna daging lebih kuning dari awal pengamatan, sedangkan sampel dengan perlakuan konsentrasi $0,05 \%$ cenderung mengalami penurunan. Sampel dengan perlakuan konsentrasi $0,15 \%$ adalah yang paling stabil fluktuasinya. Pada daging sapi terdapat lemak marbling. Marbling adalah butiran lemak putih yang tersebar dalam jaringan otot daging (lemak intra muskuler) (SNI, 2008). Lemak marbling tidak mempengaruhi mioglobin dan hemoglobin, tetapi lemak daging segar kadang-kadang berwarna kuning karena akumulasi pigmen karotenoid di dalam jaringan (Nurwantoro dan Mulyani, 2003). Disebutkan juga oleh Nurwantoro dan Mulyani (2003) bahwa daging yang berwarna kuning cenderung berkualitas rendah. Pada penelitian yang dilakukan oleh Shon et. al. (2010) juga didapatkan bahwa pada parameter kekuningan $\left(b^{*}\right)$ nilai cenderung menurun yang kemungkinan disebabkan oleh oksidasi lipid yang menyebabkan perubahan warna. Dan tidak ditemukan perbedaan nilai warna kekuningan antara daging sapi yang diberi perlakuan coating isolat protein kedelai dan daging sapi yang tidak diberi perlakuan coating isolat protein kedelai. Sehingga dapat disimpulkan bahwa perlakuan coating tidak mempengaruhi nilai parameter warna kekuningan.

\section{KESIMPULAN}

Hasil penelitian menunjukkan bahwa penambahan oleoresin daun jeruk purut pada edible coating daging sapi berpengaruh terhadap kerusakan oksidatif dan mikrobiologis daging sapi. Penambahan oleoresin daun jeruk purut menurunkan jumlah mikroba dan menstabilkan nilai TVB dan TBA. Nilai pH tidak berubah secara signifikan selama penyimpanan.Semakin besar penambahan oleoresin warna daging sapi semakin stabil.

\section{UCAPAN TERIMA KASIH}

Peneliti mengucapkan terimakasih kepada Direktorat Jendral Pendidikan Tinggi yang telah membiayai penelitian ini melalui Program Desentralisasi Penelitian Unggulan Perguruan Tinggi 2012.

\section{DAFTAR PUSTAKA}

Ali, F. H., G. M. Kassem, and O. A. AttaAlla. 2010. Propolis as a Natural Decontaminant and Antioxidant in Fresh Oriental Sausage. Veterinaria Italiana, 46 (2): 167-172.

Aryani, N. T. 2012. Ekstraksi Maserasi Oleoresin Daun Jeruk Purut (Citrus hystrix DC) : Optimasi Rendemen dan Pengujian Karakteristik Mutu. Skripsi. UNS. Surakarta.

Boles, J. A. and R. Pegg. 1998. Meat Color. Montana State University and Saskatchewan Food Product Innovation Program University of Saskatchewan.

Buckle, K. A., R. A. Edwards, G. H. Fleet, and M. Wootton. 1987. Ilmu Pangan. Universitas Indonesia Press. Jakarta.

Camo, J., A. Lores, D. Djenane, J. A. Beltran, and P. Roncales. 2011. Display Life of Beef Packaged with an Antioxidant Active Film as a Function of the Concentration of Oregano Extract. Meat Science 88:174-178.

Chanthaphon, S., S. Chanthachum and T. Hongpattarakere. 2008. Antimicrobial Activities of Essential Oils and Crude Extracts From Tropical Citrus Spp. Against Food-Related Microorganisms. Songklanakarin J. Sci. Technol. 30 (Suppl.1), 125-131, April 2008. Thailand.

Cushnie, T. P. T. and A. J. Lamb. 2005. Antimicrobial Activity of Flavonoids. International Journal of Antimicrobial Agents 26: 343-356

Devi, N. F., F. Yulianti, dan Andrini. 2010. Kandungan Flavonoid dan Limonoid pada Berbagai Fase Pertumbuhan 
Tanaman Jeruk Kalamondin (Citrus mitis Blanco) dan Purut (Citrus hystrix Dc.). J. Hort. 20(1): 360-367.

Foragri. 2012. Budidaya Jeruk Purut. http://foragri.wordpress.com/2012/04/ 09/budi-daya-jeruk-purut/. Diakses pada tanggal 20 Februari 2013 pukul 23.31 WIB.

Kasmadiharja, H. 2008. Kajian Penyimpanan Sosis, Naget Ayam dan Daging Ayam Berbumbu dalam Kemasan Polipropilen Rigrid. Skripsi. IPB. Bogor.

Keawsa-ard, S. and S. Kongtaweelert. 2012. Antioxidant, Antibacterial, Anticancer Activities and Chemical Constituents of the Essential Oil from Mesua ferrea Leaves. Chiang Mai J. Sci. 39(3): 455-463

Kingchaiyamphum, W. and C. Rachtanapun. 2012. Antimicrobial and Antioxidative Activities of Essential Oils Iin Chinese Sausage (KunChiang). As. J. Food Ag-Ind. 5(02): 156-162.

Komariah, I, I. Arief, dan Y. Wiguna. 2004. Kualitas Fisik dan Mikroba Daging Sapi yang Ditambah Jahe (Zingiber officinale Roscoe) pada Konsentrasi dan Lama Penyimpanan yang Berbeda. Media Peternakan Vol. 27 N0. 2: 46-54

Nanasombat, N. and P. Lohasupthawee. 2005. Antibacterial Activity of Crude Ethanolic Extracts and Essential Oils of Spices Against Salmonellae and Other Enterobacteria. KMITL Sci. Tech. J. Vol. 5 No. 3

Nurwantoro dan S. Mulyani. 2003. Buku Ajar Dasar Teknologi Hasil Ternak. Fakultas Peternakan Universitas Diponegoro. Semarang.

Olivas, G. I. and Barbosa-Canovas G. V. 2005. Edible Coatings for Fresh-cut Fruits. Critical Reviews in Food Science and Nutrition 45 (8): 657-670.

Shon, J., J. Eo, and J. Eun. 2010. Effect of Soy Protein Isolate Coating on
Quality Attributes of Cut Raw HanWoo (Korean Cow) Beef, Aerobically Packaged and Held Refrigerated. Journal of Food Quality 33: 42-60. DOI: $10.1111 / \mathrm{j} .1745-$ 4557.2010.00332.x

SNI. 2008. SNI 3932:2008 Mutu Karkas dan Daging Sapi. Badan Standardisasi Nasional. 